\title{
Synthesis of Gibberellic Acid Derivatives and Their Effects on Plant Growth
}

\author{
Hao Tian ${ }^{1,2}$, Yiren $\mathrm{Xu}^{2}$, Shaojin Liu ${ }^{1}$, Dingsha Jin ${ }^{1}$, Jianjun Zhang ${ }^{2}$, Liusheng Duan ${ }^{1}$ \\ and Weiming Tan ${ }^{1, *}$ \\ 1 Engineering Research Centre of Plant Growth Regulators, Ministry of Education, College of Agronomy and \\ Biotechnology, China Agricultural University, Beijing 100193, China; tianhao2013@cau.edu.cn (H.T.); \\ liusj9112@126.com (S.L.); jindingsha@163.com (D.J.); duanlsh@cau.edu.cn (L.D.) \\ 2 Department of Applied Chemistry, College of Science, China Agricultural University, Beijing 100193, China; \\ ryandota@sina.com (Y.X.); zhangjianjun@cau.edu.cn (J.Z.) \\ * Correspondence: tanwm@cau.edu.cn; Tel.: +86-10-6273-2039
}

Academic Editor: Roman Dembinski

Received: 7 April 2017; Accepted: 23 April 2017; Published: 26 April 2017

\begin{abstract}
A series of novel C-3-OH substituted gibberellin derivatives bearing an amide group were designed and synthesized from the natural product gibberellic acid $\left(\mathrm{GA}_{3}\right)$. Their activities on the plant growth regulation of rice and Arabidopsis were evaluated in vivo. Among these compounds, 10d and 10f exhibited appreciable inhibitory activities on rice $(48.6 \%$ at $100 \mu \mathrm{mol} / \mathrm{L})$ and Arabidopsis $(41.4 \%$ at $100 \mu \mathrm{mol} / \mathrm{L})$, respectively. These results provide new insights into the design and synthesis of potential plant growth regulators.
\end{abstract}

Keywords: gibberellin derivatives; natural products; Huisgen reaction; amide; plant growth regulators

\section{Introduction}

Plant growth regulators (PGRs) are organic compounds that can promote, inhibit or modify physiological processes in plants [1]. Various synthetic PGRs, such as uniconazole, mepiquat chloride, and daminozide (Figure 1) have been widely used to regulate plant growth and ensure ultimate harvesting. Although these compounds are effective, there have been increasing concerns from consumers' point of view regarding the potential harmful side effects of these chemical agents. This, in turn, has led people to pay more attention to products of natural origin, potentially presenting less likely adverse side effects.

Gibberellins (GAs) are a large family of natural products that regulate many developmental processes in plants, including seed germination, stem elongation, and induction of flowering [2]. Over the years, more than a hundred GAs have been identified from organisms, amongst which only few compounds are available in large quantities such as the relatively cheap natural derived phytohormone named gibberellic acid $\left(\mathrm{GA}_{3}\right)$ (Figure 2). The latter can be obtained by fermentation of the fungus Gibberella fujikuroi [3]. Moreover, $\mathrm{GA}_{3}$ presents an ideal molecule platform for chemical modifications, as it is a tetracyclic diterpenoid compound containing two hydroxyl groups, a lactone ring, and a carboxyl group. Besides, $\mathrm{GA}_{3}$ derivatives featuring diverse structures could exhibit different biological functions from parent molecule $\mathrm{GA}_{3}[4,5]$. For example, 7-homo-GA $\mathrm{A}_{3}$ and 16,17-dihydro-GA inhibited stem elongation, meanwhile 16,17-dichloromethano-dihydro- $\mathrm{GA}_{3}$ had an inhibitory effect on both stem elongation and flowering in Lolium temulentum [6,7]. In addition, some gibberellin derivatives characterized by an $\alpha, \beta$-unsaturated ketone moiety even exhibited anti-tumor bioactivities $[8,9]$. However, other chemical modifications could be undertaken on the $\mathrm{GA}_{3}$ that could lead to new relevant biological effects. 
Many PGRs regulate the growth of plants and contain an amide group, such as daminozide and carbaryl. Taking into consideration the chemical group, we believed that modified $\mathrm{GA}_{3}$ derivatives characterized by amide groups could provide interesting bioactivities to the target compounds. As part of our research in the field of PGRs [10-13], we report herein the synthesis of a series of novel $\mathrm{C} 3-\mathrm{OH}$ substituted $\mathrm{GA}_{3}$ derivatives bearing an amide moiety. To reach this aim, we applied a Huisgen 'click' cycloaddition [14] because it proceeds via the formation of a highly proteolytic and metabolic stable intermediate presenting a triazole moiety [15]. Besides, Mander and co-workers reported that the addition of an acetate group at the $\mathrm{C} 13$ position of 16,17-dihydro-GA $\mathrm{A}_{5}$ increased the inhibition efficacy of the molecule towards graminaceous species [16]. Following this interesting result, we also acetylated the hydroxyl group at the $\mathrm{C} 13$ position of our target compounds. Fifteen new gibberellin derivatives were synthesized, and their inhibitory activities towards rice (Oryza sativa L.) and Arabidopsis were evaluated.
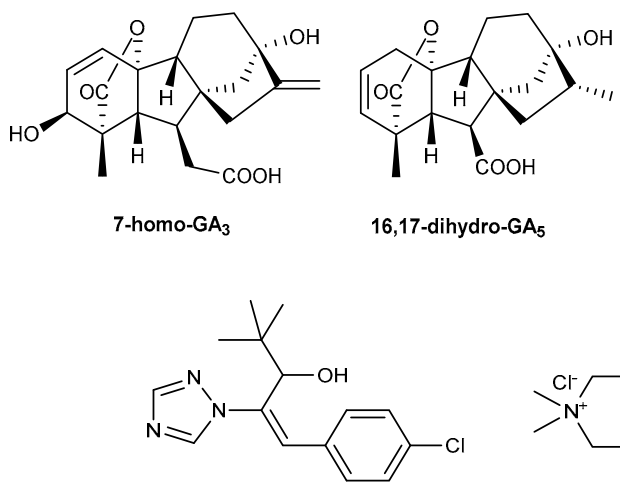

Uniconazole

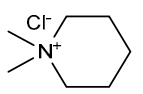

Mepiquat
chloride

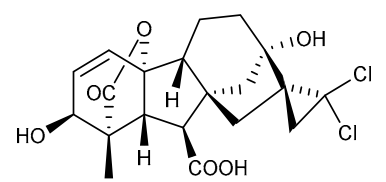

16,17-dichloromethano-dihydro-GA 3

(a)

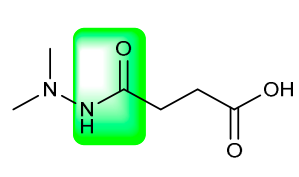

Daminozide

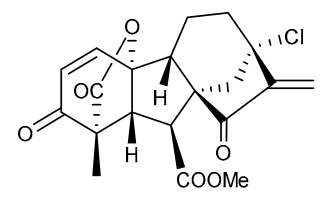

13-chlorine-3,15-dioxy-GA ${ }_{3}$ methyl ester

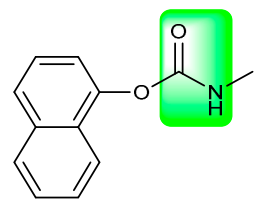

Carbaryl

(b)

Figure 1. Gibberellic acid $\left(\mathrm{GA}_{3}\right)$ derivatives (a) and commercially available synthetic plant growth regulators (PGRs) (b).
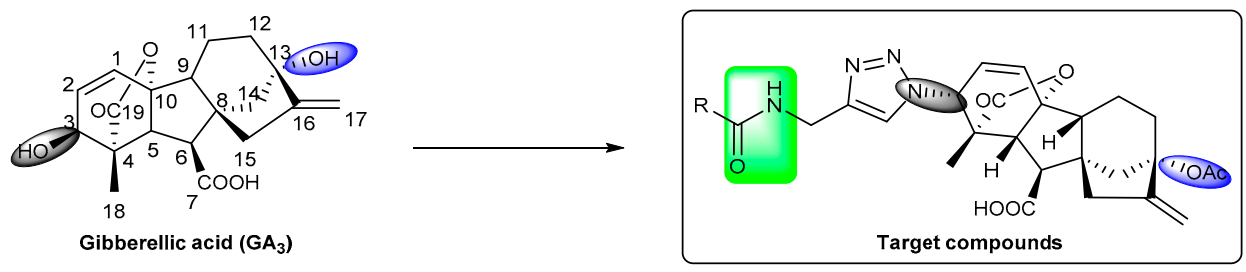

Figure 2. The molecular design of target compounds.

\section{Results and Discussion}

\subsection{Synthesis}

Firstly, all the targeted compounds were prepared starting by the synthesis of the precursor, $3 \alpha$-azido-13-acetate-7-(2,4-dimethoxybenzyl) ester-GA 6 (Scheme 1). GA 3 (1) was peracetylated [17] in the presence of dimethylaminopyridine (DMAP), acetic anhydride in pyridine afforded 3,13-diacetylated $\mathrm{GA}_{3}$ (2). Then, compound 2 was treated with 2,4-dimethoxybenzyl alcohol in dichloromethane at $0{ }^{\circ} \mathrm{C}$ in the presence of 1-Ethyl-3-(3-dimethylaminopropyl)-carbodiimide hydrochloride (EDCI) and DMAP, producing the 3,13-diacetates-GA 3 ester 3 in high yield [18]. Subsequently, the selective deacetylation $[19,20]$ of 3 with potassium carbonate in methanol afforded the 3-hydroxyl-13-acetate-GA $\mathrm{GA}_{3}$ ester 4 . At this point of the synthesis, the structure of compound 4 was confirmed by comparing the ${ }^{1} \mathrm{H}-\mathrm{NMR}$ spectra of compounds 3 with 4 . We observed an up-field 
shift of the signal assigned to $\mathrm{H}-3$ ( $\delta 5.36 \mathrm{ppm}$ in $3 \mathrm{vs.} \delta 4.16 \mathrm{ppm}$ in 4 ), confirming the conversion of compound 3 into 4 . Methyl sulfonylation of 4 with mesyl chloride in pyridine provided the 3-mesyl-13-acetate-GA 3 ester 5 , which was subjected to a nucleophilic attack with sodium azide in $\mathrm{N}, \mathrm{N}$-Dimethylformamide (DMF) to result in the expected $\mathrm{SN}_{2}$ product 6 . The comparison of the ${ }^{1} \mathrm{H}-\mathrm{NMR}$ spectra of compounds 5 and $\mathbf{6}$ indicated that the characteristic signal of $\mathrm{H}-3$ shifted to the up-field region after nucleophilic substitution $(\delta 5.07 \mathrm{ppm}$ in $5 \mathrm{vs} . \delta 4.05 \mathrm{ppm}$ in 6$)$. The obtention of a single crystal of $\mathbf{6}$ (Scheme 1) permitted the elucidation of the full configuration by X-ray diffraction.
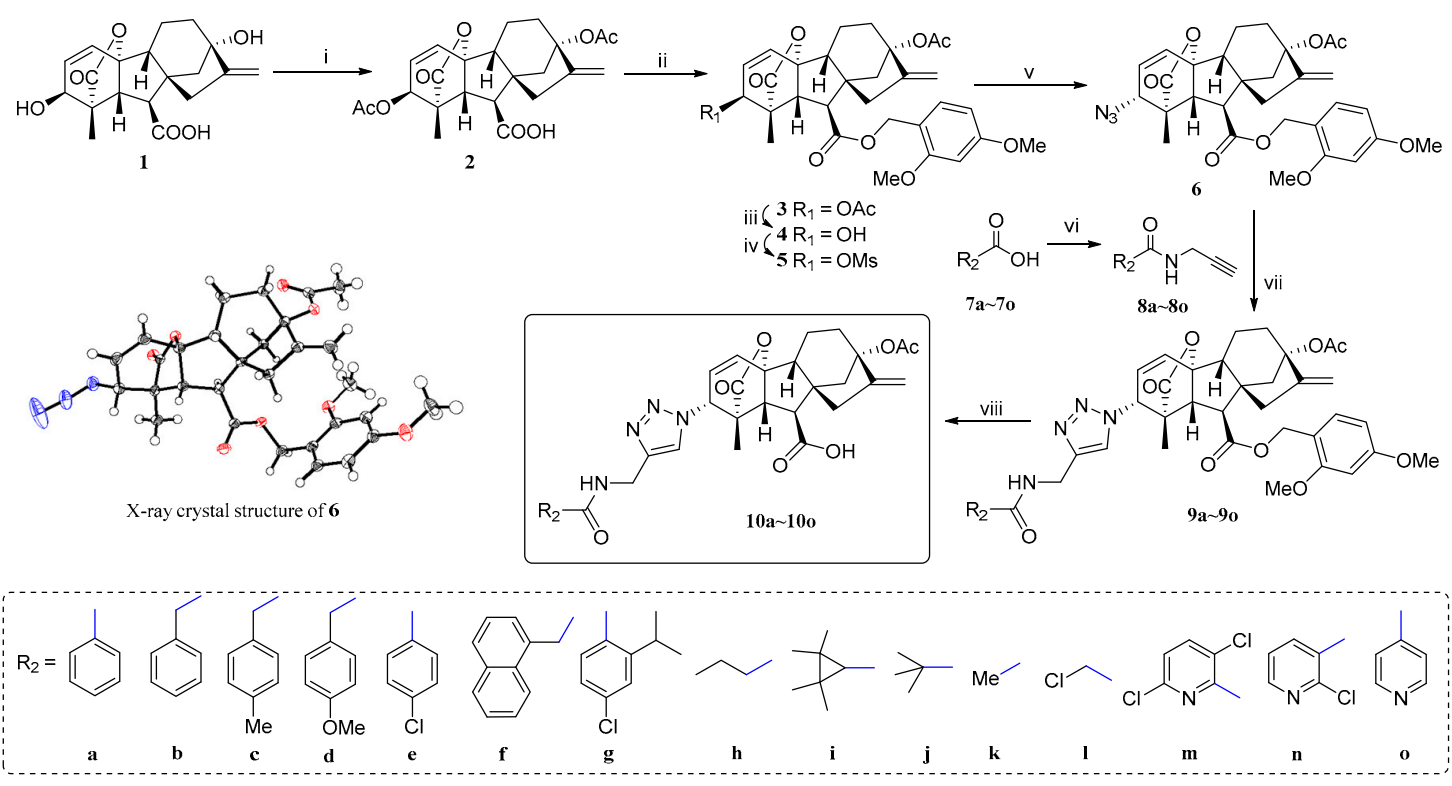

Scheme 1. Total synthesis of the target compounds. Reagents and conditions: (i) $\mathrm{Ac}_{2} \mathrm{O}, \mathrm{DMAP}, \mathrm{Py}$, r.t., $24 \mathrm{~h}$, yield 98\%; (ii) 2,4-dimethoxybenzyl alcohol, EDCI, DMAP, $\mathrm{CH}_{2} \mathrm{Cl}_{2}, 0^{\circ} \mathrm{C}$, r.t., $3 \mathrm{~h}$, yield $85 \%$; (iii) $\mathrm{K}_{2} \mathrm{CO}_{3}, \mathrm{MeOH}: \mathrm{H}_{2} \mathrm{O}$ at a ratio of 4:1 vt, $\mathrm{pH} 9 \sim 10,0.5 \mathrm{~h}$, yield $83 \%$; (iv) $\mathrm{MsCl}, \mathrm{Py}, 0^{\circ} \mathrm{C}$, r.t., 3 h, yield $95 \%$; (v) $\mathrm{NaN}_{3}$, Dimethylformamide (DMF), $60^{\circ} \mathrm{C}, 3 \mathrm{~h}$, yield $89 \%$; (vi) a. oxalyl chloride, $\mathrm{DMF}, \mathrm{CH}_{2} \mathrm{Cl}_{2}$, $3 \mathrm{~h}$; b. propargylamine, triethylamine $\left(\mathrm{Et}_{3} \mathrm{~N}\right), \mathrm{CH}_{2} \mathrm{Cl}_{2}, 3 \mathrm{~h}$, yield $82-99 \%$; (vii) $\mathrm{NaAsc} \mathrm{CuSO}_{4} \cdot 5 \mathrm{H}_{2} \mathrm{O}$, $\mathrm{MeOH} / \mathrm{CH}_{2} \mathrm{Cl}_{2} / \mathrm{H}_{2} \mathrm{O}=1 / 8 / 1,24 \mathrm{~h}$, yield $72-88 \%$; (viii) $\mathrm{ZnCl}_{2}, \mathrm{CH}_{2} \mathrm{Cl}_{2}, 0.5 \mathrm{~h}$, yield $71-90 \%$.

Secondly, fifteen different carboxylic acids containing phenylic, aliphatic, and pyridyl groups (7a-7o) were selected as the initial materials to perform acyl chlorination [21] with oxalyl chloride and DMF in dichloromethane (Scheme 1). The acyl chloride substrates were subjected to amidation with mono-propargylamine and triethylamine in dichloromethane to afford the alkynyl carboxamides (8a-8o). Then, the expected target compounds presenting the protection groups $(\mathbf{9 a}-\mathbf{9 o})$ were formed by the fusion of a specific azide intermediate 6 with the terminal alkyne group of the corresponding alkynyl carboxamide (8a-8o) via a Huisgen 'click' cycloaddition [14,22]. Finally, the protecting groups were selectively removed following typical procedures from literature $[23,24]$. Shortly, the 2,4-dimethoxybenzyl esters could be readily oxidized by 2,3-dichloro-5,6-dicyano benzoquinone (DDQ) to generate the corresponding carboxylic acids. Unexpectedly, we did not obtain the target compounds (10a-10o) according to this method. Indeed, this specific carboxylic acid is prone to a different acidic character when compared to a simple carboxylic acid. Moreover, the funtional groups in the ring A of $\mathrm{GA}_{3}$ were quite sensitive under many reaction conditions $[4,7,25]$. In order to overcome the difficulty described above, a series of thorough experiments were carried out. Fortunately, we found that zinc dichloride used as a catalyst could cleave the 2,4-dimethoxylbenzyl esters (9a-9o) to successfully obtain the corresponding carboxylic acids (10a-10o) without affecting other sensitive functional groups such as lactone, acetyl, amide, or triazole group. This method offered a practical protective strategy for 
complex structures. The molecular structure of the intermediates and target compounds was confirmed by ${ }^{1} \mathrm{H}$ - and ${ }^{13} \mathrm{C}-\mathrm{NMR}$ spectroscopy and High-resolution mass spectra (HRMS).

\subsection{Biological Activities towards Arabidopsis and Rice}

To examine whether the fifteen prepared synthetic $\mathrm{GA}_{3}$ derivatives $(\mathbf{1 0 a}-\mathbf{1 0 0})$ could trigger a dwarf or elongated phenotype in Arabidopsis, the hypocotyl length of Arabidopsis seedlings and the second leaf sheath length of rice were used as the activity indicators [26,27], respectively.

The in vivo activities of the synthesized $\mathrm{GA}_{3}$ derivatives (10a-10o) obtained from the measurements of the hypocotyl lengths and the second leaf sheath are summarized in Table 1. As expected, compound 10f exhibited the highest inhibitory activities (41.4\%) on Arabidopsis. In contrast, the rice bioassays resulted in a higher number of compounds presenting more remarkable inhibitory activity than for Arabidopsis. Compound $\mathbf{1 0 d}$ had the best results with an inhibition rate of $48.6 \%$ on rice, different from the results obtained for Arabidopsis (10f). Therefore, we observed a discrepancy in the inhibition activity of the $\mathrm{GA}_{3}$ derivatives towards these two plants. The discrepancy in the inhibition activity of the $\mathrm{GA}_{3}$ derivatives towards the two different plants could come from the fact that the plants are complex organisms, in which the enzymes involved in the growth of Arabidopsis and rice are still not yet fully identified. On the whole, the molecular size of the substituent group could play an important role in the inhibition activities towards Arabidopsis. In rice, the benzene ring presenting more electron donating groups and less aliphatic hydrocarbons should present more inhibition activities. In addition, the moderate activities suggested a new direction for the development of these compounds to be used as new plant-type regulators that could specifically target crops and ornamental plants in the agricultural industry.

Table 1. In vivo activities of the synthetic $\mathrm{GA}_{3}$ derivatives $(100 \mu \mathrm{M})$.

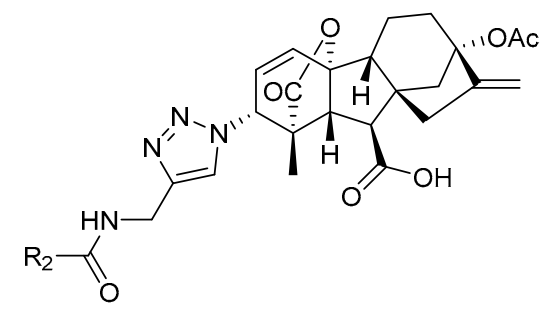

\begin{tabular}{|c|c|c|}
\hline \multirow{2}{*}{ Compound No. } & \multicolumn{2}{|c|}{ Length $(\mathrm{cm})^{a}$} \\
\hline & Arabidopsis & Rice \\
\hline $10 a$ & $1.48 \pm 0.27$ & $1.89 \pm 0.36$ \\
\hline $10 b$ & $1.40 \pm 0.14$ & $2.16 \pm 0.38$ \\
\hline $10 c$ & $1.54 \pm 0.20$ & $1.83 \pm 0.27 *$ \\
\hline 10d & $1.55 \pm 0.20$ & $1.47 \pm 0.20 *$ \\
\hline $10 \mathrm{e}$ & $1.39 \pm 0.17$ & $1.98 \pm 0.35$ \\
\hline $10 f$ & $0.88 \pm 0.15^{*}$ & $2.13 \pm 0.32$ \\
\hline $10 \mathrm{~g}$ & $1.06 \pm 0.15$ & $2.01 \pm 0.30$ \\
\hline $10 \mathrm{~h}$ & $1.54 \pm 0.25$ & $2.43 \pm 0.39$ \\
\hline $10 \mathrm{i}$ & $1.43 \pm 0.20$ & $2.72 \pm 0.28$ \\
\hline $10 \mathrm{j}$ & $1.55 \pm 0.23$ & $2.26 \pm 0.28$ \\
\hline $10 \mathrm{k}$ & $1.53 \pm 0.25$ & $2.61 \pm 0.21$ \\
\hline 101 & $1.37 \pm 0.20$ & $2.22 \pm 0.24$ \\
\hline $10 \mathrm{~m}$ & $1.43 \pm 0.20$ & $2.12 \pm 0.51$ \\
\hline $10 n$ & $1.05 \pm 0.18$ & $2.04 \pm 0.41$ \\
\hline $10 \mathrm{o}$ & $1.43 \pm 0.14$ & $2.49 \pm 0.29$ \\
\hline Blank control & $1.50 \pm 0.21$ & $2.86 \pm 0.36$ \\
\hline Uniconazole & $0.12 \pm 0.03^{* *}$ & $1.07 \pm 0.11^{* *}$ \\
\hline $\mathrm{GA}_{3}$ & $1.77 \pm 0.22 *$ & $5.40 \pm 0.48^{* *}$ \\
\hline
\end{tabular}

${ }^{*} p<0.05,{ }^{* *} p<0.01,{ }^{\text {a }}$ Data are mean values \pm the standard deviation obtained from three independent experiments. 


\section{Materials and Methods}

\subsection{General Information}

Solvents were purified according to standard procedure. All commercially available reagents were used without further purification. All the solvents were purchased at Sinopharm, Shanghai, China. The following compounds $\mathrm{GA}_{3}$; dimathylaminopyridine (DMAP); acetic anhydride; anhydrous pyridine; hydrochloric acid; dichloromethane; anhydrous sodium sulfate; ethyl acetate; light petroleum; 1-Ethyl-3-(3-dimethylaminopropyl)carbodiimide (EDCI); 2,4-dimethoxybenzyl alcohol; methanol; methylsulfonyl chloride; oxalyl chloride; propargylamine; sodium sulfate; sodium ascorbate; chalcanthite; and celite were purchased at Coupling technology co., LTD, Beijing, China. The seeds of Arabidopsis and rice were provided by the department of breeding and seed engineering of the China Agriculture University, Beijing.

All reactions were monitored by TLC or by iodine fuming detection. Column chromatography was conducted on a silica gel plug (200-300 mesh) using a mixture of ethyl actetate (EtOAc) and petroleum ether (b.p. $60-90^{\circ} \mathrm{C}$ ) as the eluent. The ${ }^{1} \mathrm{H}$ - and ${ }^{13} \mathrm{C}-\mathrm{NMR}$ spectra were recorded on Bruker DPX300 (300 MHz and $75 \mathrm{MHz}$ ) and Bruker AVANCE 600 spectrometers with samples dissolved in deuterated chloroform $\left(\mathrm{CDCl}_{3}\right)$ or deuterated dimethyl sulfoxide (DMSO- $\left.d_{6}\right)$. The internal reference was tetramethyl silane TMS $\left(\delta=0.000 \mathrm{ppm}\right.$ for ${ }^{1} \mathrm{H}$ and $\left.{ }^{13} \mathrm{C}\right)$. High-resolution mass spectra (HRMS) were performed at the Peking University acquired with an Agilent 6520 Accurate-Mass-Q-TOF LC/MS system equipped with Electrospray ionization (ESI) source in the positive ionization mode. Solutions were concentrated at a temperature $<60^{\circ} \mathrm{C}$ under diminished pressure.

\subsection{Chemical Synthesis}

Synthesis of 3,13-Acetoxy-ent-10 $\beta$-hydroxy-20-norgibberella-1,16-diene-7,19-dioic acid-19,10-lactone (2). A mixture of compound 1 [ 4 ] (50 g, $144.4 \mathrm{mmol})$, acetic anhydride (150 mL), and DMAP $(0.18 \mathrm{~g}, 1.4 \mathrm{mmol})$ in anhydrous pyridine $(200 \mathrm{~mL})$ was stirred at room temperature overnight. The solution was diluted with water $(50 \mathrm{~mL})$ under an ice bath then acidified until reaching a $\mathrm{pH}$ value of 2 with diluted hydrochloric acid and finally extracted with dichloromethane $(3 \times 150 \mathrm{~mL})$. The organic layers were pooled and dried over anhydrous sodium sulfate. The solvent was evaporated under reduced pressure and the residue was recrystallized in a 50\% vt solution of ethyl acetate and light petroleum to give $\mathrm{GA}_{3}$ 3,13-diacetate (2). The analytical results of compound 2 were identical to the one described in the literature [28]. White solid, yield 98\%, ${ }^{1} \mathrm{H}-\mathrm{NMR}\left(300 \mathrm{MHz}, \mathrm{CDCl}_{3}\right): \delta 6.39(\mathrm{~d}, J=9.3 \mathrm{~Hz}, 1 \mathrm{H}), 5.90(\mathrm{dd}$, $J=9.3,3.8 \mathrm{~Hz}, 1 \mathrm{H}), 5.36(\mathrm{~d}, J=3.8 \mathrm{~Hz}, 1 \mathrm{H}), 5.20(\mathrm{~d}, J=1.7 \mathrm{~Hz}, 1 \mathrm{H}), 5.04(\mathrm{~s}, 1 \mathrm{H}), 3.31(\mathrm{~d}, J=11.0 \mathrm{~Hz}, 1 \mathrm{H})$, $2.84(\mathrm{~d}, J=11.0 \mathrm{~Hz}, 1 \mathrm{H}), 2.51-2.20(\mathrm{~m}, 6 \mathrm{H}), 2.15(\mathrm{~s}, 3 \mathrm{H}), 2.05(\mathrm{~s}, 3 \mathrm{H}), 2.01-1.81(\mathrm{~m}, 3 \mathrm{H}), 1.22(\mathrm{~s}, 3 \mathrm{H})$.

Synthesis of 3,13-Acetoxy-ent-10 $\beta$-hydroxy-20-norgibberella-1,16-diene-7,19-dioic acid-7-(2,4-dimethoxybenzyl) ester-19,10-lactone (3). To a solution of 2 (50 g, $116.2 \mathrm{mmol})$ dissolved in dichloromethane (300 $\mathrm{mL})$, EDCI (33.4 g, $174.3 \mathrm{mmol})$ was slowly added followed by the addition of DMAP $(0.14 \mathrm{~g}, 1.7 \mathrm{mmol})$ at $0{ }^{\circ} \mathrm{C}$. After stirring at r.t. for $15 \mathrm{~min}$, a solution of 2,4-dimethoxybenzyl alcohol $(19.54 \mathrm{~g}, 116.2 \mathrm{mmol})$ dissolved in $80 \mathrm{~mL}$ of dichloromethane was added dropwise at $0{ }^{\circ} \mathrm{C}$. After stirring the mixture at r.t. for $3 \mathrm{~h}$, the reaction mixture was washed with diluted hydrochloric acid $(1 \mathrm{M}, 100 \mathrm{~mL})$ and extracted with dichloromethane $(3 \times 150 \mathrm{~mL})$. The combined organic layers were pooled and washed with a solution of saturated brine, then dried over anhydrous sodium sulfate followed by solvent evaporation under reduced pressure. The product was recrystallized in methanol to give 3 . White solid, yield 85\%, m.p. $156-157{ }^{\circ} \mathrm{C} .{ }^{1} \mathrm{H}-\mathrm{NMR}\left(300 \mathrm{MHz}, \mathrm{CDCl}_{3}\right): \delta 7.23(\mathrm{~d}, J=8.5 \mathrm{~Hz}, 1 \mathrm{H}), 6.47-6.43$ (m, $\left.2 \mathrm{H}\right), 6.35$ $(\mathrm{dd}, J=9.3,0.6 \mathrm{~Hz}, 1 \mathrm{H}), 5.85(\mathrm{dd}, J=9.3,3.8 \mathrm{~Hz}, 1 \mathrm{H}), 5.31(\mathrm{~d}, J=3.8 \mathrm{~Hz}, 1 \mathrm{H}), 5.19-5.18(\mathrm{~m}, 1 \mathrm{H})$, 5.16-5.07 (m, $2 \mathrm{H}), 4.94(\mathrm{~s}, 1 \mathrm{H}), 3.80(\mathrm{~s}, 3 \mathrm{H}), 3.77(\mathrm{~s}, 3 \mathrm{H}), 3.31(\mathrm{~d}, J=11.0 \mathrm{~Hz}, 1 \mathrm{H}), 2.77(\mathrm{~d}, J=11.0 \mathrm{~Hz}$, $1 \mathrm{H}), 2.44-2.11(\mathrm{~m}, 5 \mathrm{H}), 2.09(\mathrm{~s}, 3 \mathrm{H}), 2.01(\mathrm{~s}, 3 \mathrm{H}), 1.96-1.62(\mathrm{~m}, 4 \mathrm{H}), 1.13(\mathrm{~s}, 3 \mathrm{H}) .{ }^{13} \mathrm{C}-\mathrm{NMR}(75 \mathrm{MHz}$, $\left.\mathrm{CDCl}_{3}\right): \delta 176.68,171.36,169.63,169.26,161.26,158.71,153.46,133.96,131.47,128.72,115.59,107.77$, 
$103.63,98.11,89.61,83.78,69.87,62.53,55.03,54.97,52.96,51.77,50.71,50.09,41.86,39.72,35.63,21.60$, 20.39, 16.54, 13.88. HRMS for $\mathrm{C}_{32} \mathrm{H}_{40} \mathrm{NO}_{10}\left(\mathrm{M}+\mathrm{NH}_{4}\right)^{+}$598.2647. Found: 598.2648.

Synthesis of 13-Acetoxy-ent-3 $\alpha, 10 \beta$-dihydroxy-20-norgibb-erella-1,16-diene-7,19-dioic acid-7-(2,4-dimethoxybenzyl) ester-19,10-lactone (4). To a solution of compound 3 (40 g, $68.9 \mathrm{mmol})$ dissolved in methanol (300 mL) was slowly added a saturated potassium carbonate solution dropwise until the $\mathrm{pH}$ value of the mixture reached 9-10. Then, the solution was stirred at r.t. for $40 \mathrm{~min}$. The reaction mixture was acidified until reaching a $\mathrm{pH}$ value of 7 with a hydrochloric acid solution $(1 \mathrm{M})$. The reaction mixture was washed with water $(100 \mathrm{~mL})$ and then with a solution of saturated brine $(150 \mathrm{~mL})$ after extraction with dichoromethane $(3 \times 100 \mathrm{~mL})$ to yield 4 without further purification. White solid, yield $83 \%$, m.p. ${ }^{125-126}{ }^{\circ} \mathrm{C} .{ }^{1} \mathrm{H}-\mathrm{NMR}\left(300 \mathrm{MHz}, \mathrm{CDCl}_{3}\right): \delta 7.27(\mathrm{~d}, J=8.2 \mathrm{~Hz}, 1 \mathrm{H}), 6.50-6.47(\mathrm{~m}, 2 \mathrm{H}), 6.33$ $(\mathrm{d}, J=9.4 \mathrm{~Hz}, 1 \mathrm{H}), 5.93(\mathrm{dd}, J=9.3,3.7 \mathrm{~Hz}, 1 \mathrm{H}), 5.21(\mathrm{~s}, 1 \mathrm{H}), 5.19-5.10(\mathrm{~m}, 2 \mathrm{H}), 4.98(\mathrm{~s}, 1 \mathrm{H}), 3.84$ (s, $3 \mathrm{H}), 3.81(\mathrm{~s}, 3 \mathrm{H}), 3.23(\mathrm{~d}, J=10.9 \mathrm{~Hz}, 1 \mathrm{H}), 2.82(\mathrm{~d}, J=10.9 \mathrm{~Hz}, 1 \mathrm{H}), 2.47-2.09(\mathrm{~m}, 6 \mathrm{H}), 2.04(\mathrm{~s}$, $3 \mathrm{H}), 1.98-1.74(\mathrm{~m}, 3 \mathrm{H}), 1.25(\mathrm{~s}, 3 \mathrm{H}) .{ }^{13} \mathrm{C}-\mathrm{NMR}\left(75 \mathrm{MHz}, \mathrm{CDCl}_{3}\right): \delta 178.24,171.80,169.42,161.23$, 158.71, 153.50, 132.30, 131.48, 115.61, 107.69, 103.63, 98.12, 90.03, 83.92, 69.35, 62.61, 55.05, 54.98, 53.16, $52.35,50.85,50.77,41.89,39.80,35.68,21.63,16.58,14.00$. HRMS for $\mathrm{C}_{30} \mathrm{H}_{38} \mathrm{NO}_{9}\left(\mathrm{M}+\mathrm{NH}_{4}\right)^{+} 556.2541$. Found: 556.2546.

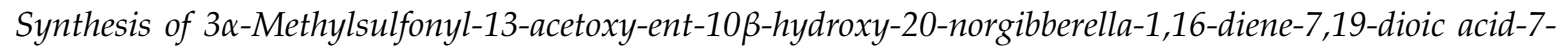
(2,4-dimethoxybenzyl) ester-19,10-lactone (5). To a solution of compound 4 (30 g, $55.7 \mathrm{mmol})$ dissolved in anhydrous pyridine $(150 \mathrm{~mL})$ was slowly added a solution of methylsulfonyl chloride $(6.38 \mathrm{~g}$, $61.27 \mathrm{mmol}$ ) dissolved in dichloromethane dropwise at $0{ }^{\circ} \mathrm{C}$. After stirring the reaction mixture at r.t. for $3 \mathrm{~h}$, the mixture was washed with a solution of diluted hydrochloric acid (2 M, $500 \mathrm{~mL})$ followed by extractions with dichoromethane $(3 \times 150 \mathrm{~mL})$ to yield 5 without further purification. White solid, yield 95\%, m.p. 80-82 ${ }^{\circ} \mathrm{C}$. ${ }^{1} \mathrm{H}-\mathrm{NMR}\left(300 \mathrm{MHz}, \mathrm{CDCl}_{3}\right): \delta 7.26(\mathrm{~d}, J=8.2 \mathrm{~Hz}, 1 \mathrm{H}), 6.50(\mathrm{~s}, 1 \mathrm{H}), 6.47$ (s, $2 \mathrm{H}), 6.02(\mathrm{dd}, J=9.3,3.8 \mathrm{~Hz}, 1 \mathrm{H}), 5.22(\mathrm{~d}, J=1.4 \mathrm{~Hz}, 1 \mathrm{H}), 5.19-5.10(\mathrm{~m}, 2 \mathrm{H}), 5.07(\mathrm{~d}, J=3.8 \mathrm{~Hz}, 1 \mathrm{H})$, $4.98(\mathrm{~s}, 1 \mathrm{H}), 3.84(\mathrm{~s}, 3 \mathrm{H}), 3.81(\mathrm{~s}, 3 \mathrm{H}), 3.32(\mathrm{~d}, J=11.0 \mathrm{~Hz}, 1 \mathrm{H}), 3.08(\mathrm{~s}, 3 \mathrm{H}), 2.80(\mathrm{~d}, J=11.0 \mathrm{~Hz}, 1 \mathrm{H})$, 2.47-2.09 (m, $5 \mathrm{H}), 2.04(\mathrm{~s}, 3 \mathrm{H}), 2.01-1.72(\mathrm{~m}, 4 \mathrm{H}), 1.28(\mathrm{~s}, 3 \mathrm{H}) .{ }^{13} \mathrm{C}-\mathrm{NMR}\left(75 \mathrm{MHz}, \mathrm{CDCl}_{3}\right) \delta 175.66$, $171.01,169.32,161.29,158.75,153.25,135.40,131.55,128.16,115.52,107.93,103.65,98.12,89.47,83.68$, $62.62,55.05,55.00,52.75,52.28,50.62,50.54,50.03,41.76,39.76,38.37,35.52,21.60,16.51,14.44$. HRMS for $\mathrm{C}_{31} \mathrm{H}_{37} \mathrm{O}_{11} \mathrm{~S}(\mathrm{M}+\mathrm{H})^{+}$617.2051. Found: 617.2052.

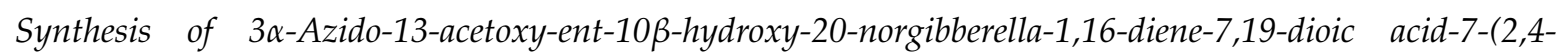
dimethoxybenzyl) ester-19,10-lactone (6). A solution containing compound 5 (30 g, $48.6 \mathrm{mmol})$ and $\mathrm{NaN}_{3}$ (9.49 g, $145.94 \mathrm{mmol})$ dissolved in anhydrous dimethyl formamide $(150 \mathrm{~mL})$ was stirred at r.t. for $3 \mathrm{~h}$. The reaction mixture was poured into iced water $(150 \mathrm{~g})$ and then extracted with ethyl acetate $(3 \times 150 \mathrm{~mL})$ to give a crude product 6 . The combined organic layers were concentrated under reduced pressure and followed by purification by silica gel chromatography to provide the intermediate 6 . White solid, yield 89\%, m.p. $126-128{ }^{\circ} \mathrm{C} .{ }^{1} \mathrm{H}-\mathrm{NMR}\left(300 \mathrm{MHz}, \mathrm{CDCl}_{3}\right): \delta 7.24(\mathrm{~d}, J=8.3 \mathrm{~Hz}, 1 \mathrm{H})$, 6.50-6.46 (m, $2 \mathrm{H}), 6.41(\mathrm{dd}, J=9.3,2.0 \mathrm{~Hz}, 1 \mathrm{H}), 5.92(\mathrm{dd}, J=9.3,2.6 \mathrm{~Hz}, 1 \mathrm{H}), 5.20(\mathrm{~s}, 1 \mathrm{H}), 5.18-5.12$ $(\mathrm{m}, 2 \mathrm{H}), 4.97(\mathrm{~s}, 1 \mathrm{H}), 4.05(\mathrm{t}, J=2.3 \mathrm{~Hz}, 1 \mathrm{H}), 3.84(\mathrm{~s}, 3 \mathrm{H}), 3.80(\mathrm{~s}, 3 \mathrm{H}), 2.99(\mathrm{~d}, J=10.7 \mathrm{~Hz}, 1 \mathrm{H}), 2.77$

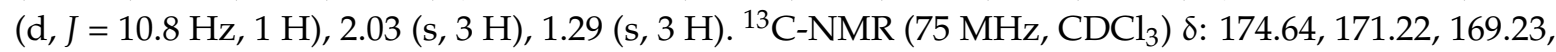
161.30, 158.72, 153.20, 132.90, 131.56, 127.98, 115.42, 107.78, 103.67, 98.07, 88.17, 83.69, 63.84, 62.68, 57.27, $55.02,54.97,52.75,50.62,50.47,50.43,41.79,39.80,35.58,21.58,16.56,14.51$. HRMS for $\mathrm{C}_{30} \mathrm{H}_{37} \mathrm{~N}_{4} \mathrm{O}_{8}$ $\left(\mathrm{M}+\mathrm{NH}_{4}\right)^{+}$581.2606. Found: 581.2605.

X-ray crystal structure of compound 6: CCDC 1541695 contains the supplementary crystallographic data for this paper. These data can be obtained free of charge via http://www. ccdc.cam.ac.uk/conts/retrieving.html (or from the CCDC, 12 Union Road, Cambridge CB2 1EZ, UK; Fax: +44 1223 336033; E-mail: deposit@ccdc.cam.ac.uk). 


\subsubsection{Synthesis of N-Prop-2-ynylamide (8a-8o)}

The compounds $8 \mathbf{a}-\mathbf{8 0}$ were all synthesized by the following general procedure. To a solution containing $7 \mathbf{a}(5 \mathrm{~g}, 40.94 \mathrm{mmol})$ and DMF $(0.05 \mathrm{~mL}, 0.65 \mathrm{mmol})$ dissolved in dichloromethane $(100 \mathrm{~mL})$ was added a solution of oxalyl chloride $(3.8 \mathrm{~mL}, 45.03 \mathrm{mmol})$ dissolved in dichloromethane $(10 \mathrm{~mL})$ dropwise at $0{ }^{\circ} \mathrm{C}$. After stirring the reaction mixture at r.t. for $3 \mathrm{~h}$, the solution was concentrated under reduced pressure to give the corresponding acyl chloride. To a solution composed of propargylamine $(3.1 \mathrm{~mL}, 45.03 \mathrm{mmol})$ and triethylamine $(8.5 \mathrm{~mL}, 61.41 \mathrm{mmol})$ dissolved in dichloromethane $(100 \mathrm{~mL})$ was added dropwise at $0{ }^{\circ} \mathrm{C}$ a solution of the corresponding acyl chloride previously dissolved in dichloromethane $(30 \mathrm{~mL})$. After stirring at r.t. for $3 \mathrm{~h}$, the mixture was washed with a solution of diluted hydrochloric acid $(1 \mathrm{M}, 100 \mathrm{~mL})$ followed by an extraction with dichloromethane $(3 \times 100 \mathrm{~mL})$. The combined organic layers were then dried over anhydrous sodium sulfate and then concentrated under reduced pressure to afford the crude product 8a. The residue was then crystallized with a mixture of ethyl acetate/petroleum ether to afford the pure product $8 \mathbf{a}$. The spectral data for the compounds 8a-8o are given in the Supporting-Information.

3.2.2. Synthesis of $3 \alpha$-(4-Amido-methyl-1H-1,2,3-trizol-1-yl)-13-acetoxy-ent-10 $\beta$-hydroxy-20norgibberella-1,16-diene-7,19-dioic acid-7-(2,4-dimethoxybenzyl) ester-19,10-lactone (9a-9o)

The compounds $9 \mathbf{a}-90$ were all synthesized by the following general procedure. To a solution containing a mixture of the corresponding compound $8 \mathrm{a}(0.47 \mathrm{~g}, 2.93 \mathrm{mmol})$ and $\mathbf{6}(1.5 \mathrm{~g}, 2.66 \mathrm{mmol})$ in dichloromethane $(16 \mathrm{~mL})$ was added slowly an aqueous solution $(2 \mathrm{ml})$ of sodium ascorbate $(5 \mathrm{mg})$ and chalcanthite $(10 \mathrm{mg})$. Methanol (ca. $2 \mathrm{~mL}$ ) was added to the reaction mixture under stirring until obtaining a homogeneous phase. Then, the solution was stirred at r.t. for $12 \mathrm{~h}$. The crude mixture was filtrated through a short plug of celite and the solvents were evaporated under reduced pressure. The residue was purified by silica gel chromatography to provide the corresponding 9a. The spectral data for the compounds $\mathbf{9 a - 9 o}$ are given in the Supporting-Information.

3.2.3. Synthesis of $3 \alpha$-(4-Amido-methyl-1H-1,2,3-trizol-1-yl)-13-acetoxy-ent-10 $\beta$-hydroxy-20norgibberella-1,16-diene-7,19-dioic acid-19,10-lactone-7-carboxyl (10a-10o)

The compounds 10a-10o were synthesized by the following general procedure. A solution containing the corresponding compound $9 \mathrm{a}(1.5 \mathrm{~g}, 2.08 \mathrm{mmol})$ and zinc chloride $\left(\mathrm{ZnCl}_{2}, 0.85 \mathrm{~g}\right.$, $6.24 \mathrm{mmol})$ dissolved in dichloromethane $(20 \mathrm{~mL})$ was stirred at r.t. for $1 \mathrm{~h}$. The mixture was then filtered through a celite plug followed by solvent evaporation under reduced pressure. The residue was purified by silica gel chromatography to provide the corresponding target compound 10a. The spectral data for the compounds 10a-10o are given in the Supporting-Information.

\subsection{Biological Activity Assay}

The inhibitory activity of all the synthesized compounds was determined in vivo by evaluating the hypocotyl length of Arabidopsis (Columbia-0, Col-0) plants according to the following experimental procedures. The $\frac{1}{2}$ Murashige-Skoog (MS) culture medium, a plant growth medium used in the laboratories for cultivation of plant cell culture, was prepared as follows: to $1 \mathrm{~L}$ of distilled water, MS (2.215 g), sucrose (10 g), and agar ( $8 \mathrm{~g})$ were added, and the $\mathrm{pH}$ was adjusted to 5.9 by adding sodium hydroxide $(5 \mathrm{M})$. The media were sterilized in a high-pressure steam sterilization pot. Seeds of Arabidopsis were sterilized in $70 \%$ ethanol for $1 \mathrm{~min}$, with $1 \%$ sodium hypochlorite solution $(w / v)$ for $15 \mathrm{~min}$ and then cleaned five times with distilled water. Seeds of Arabidopsis were grown on the $\frac{1}{2} \mathrm{MS}$ medium containing $100 \mu \mathrm{M}$ of the respective synthetic $\mathrm{GA}_{3}$ derivate. Each medium was sowed with 15 seeds and then maintained at $4{ }^{\circ} \mathrm{C}$ for two consecutive days. The seedswere then incubated at $22{ }^{\circ} \mathrm{C}$ in a growth chamber containing $60 \%$ relative humidity. All the plants were maintained in the dark during the growth period. After 6 days, the length of each hypocotyl was measured using a ImageJ software (https:/ /imagej.nih.gov/ij/index.html). 
The inhibitory activities of all the synthesized compounds were determined in vivo by evaluating the length of the second leaf sheath of rice according to the following experimental procedure. Seeds of rice (Oryza sativa L.) cultivar Nipponbare were sterilized with $2 \%$ sodium hypochlorite solution $(w / v)$ for $40 \mathrm{~min}$ and then soaked in distilled water for $24 \mathrm{~h}$ in darkness at $30^{\circ} \mathrm{C}$. The seeds were then washed with distilled water and incubated in distilled water at $30{ }^{\circ} \mathrm{C}$ until germination. When the coleoptiles were of ca. $2.0 \mathrm{~mm}$ in length after 2 days incubation, the 25 germinated seeds were planted in a $120 \mathrm{~mm} \times 120 \mathrm{~mm} \times 60 \mathrm{~mm}$ plastic box that was filled with $80 \mathrm{~mL}$ of $0.9 \%(w / v)$ agar and then placed in a growth chamber with a $16 / 8 \mathrm{~h}$ photoperiod, $30 / 24{ }^{\circ} \mathrm{C}$ day/night temperatures, $60 \%$ relative humidity, and $400 \mu \mathrm{mol}^{-2} \mathrm{~s}^{-1}$ of photon flux density. Two days later, a $1 \mu \mathrm{L}$-drop of a solution containing $100 \mu \mathrm{M}$ of the respective synthetic $\mathrm{GA}_{3}$ derivate was deposited at the gap between the coleoptile and the leaf sheath of each rice seedling. After three days, the length of the second leaf sheath of the seedlings was measured using a ruler.

The following equation was used to determine the inhibitory activity of all the synthesized compounds towards Arabidopsis and rice:

$$
I=\frac{\bar{L}_{0}-\bar{L}}{\bar{L}_{0}} \times 100 \%
$$

where $I$ was the inhibition rate, $\bar{L}_{0}$ and $\bar{L}$ were the average lengths of the hypocotyl of Arabidopsis (or the second leaf sheath of rice) in the blank test and in the presence of the target compound, respectively.

\section{Conclusions}

In summary, a series of novel $\mathrm{GA}_{3}$ derivatives characterized by the amide group were synthesized by utilizing a Huisgen reaction to fuse the amide group moiety to the main chemical skeleton of the natural product $\mathrm{GA}_{3}$. Moreover, we established a novel protection method of the carboxyl groups despite the challenging presence of other highly functionalized chemical groups. The results of an in vivo assay suggested that some of these new compounds exhibited appreciable plant growth inhibitory activities. In particular, compounds $10 \mathrm{~d}$ and $10 \mathrm{f}$ were the most effective towards rice and Arabidopsis, respectively. The discrepancy in the inhibitory activities towards the two plants could come from the inherently different biological mechanism of the two different plants. In the future, we will strive to study the detailed action of mechanism of these inhibitors.

Supplementary Materials: Supplementary materials are available online.

Acknowledgments: This work was partly supported by the National Natural Science Foundation of China (Project No. 31101109) and by the National High Technology Research and Development Program of China (Project No. 2011AA10A206).

Author Contributions: H.T., J.Z., and W.T. conceived and designed the research; H.T. and Y.X. performed the synthetic work, L.D., S.L. and D.J. was responsible for the direction of the biological research. W.T. was responsible for the correspondence of the manuscript. H.T. mainly analyzed the data and wrote the manuscript. All authors read and approved the final manuscript.

Conflicts of Interest: The authors declare no conflict of interest.

\section{References}

1. Tan, W.M.; Hou, N.; Pang, S.; Zhu, X.F.; Li, Z.H.; Wen, L.X.; Duan, L.S. Improved biological effects of uniconazole using porous hollow silica nanoparticles as carriers. Pest Manag. Sci. 2012, 68, 437-443. [CrossRef] [PubMed]

2. Shani, E.; Weinstain, R.; Zhang, Y.; Castillejo, C.; Kaiserli, E.; Chory, J.; Tsien, R.Y.; Estelle, M. Gibberellins accumulate in the elongating endodermal cells of arabidopsis root. Proc. Natl. Acad. Sci. USA 2013, 110, 4834-4839. [CrossRef] [PubMed]

3. Phuoc, L.T.; Mander, L.N.; Koshioka, M.; Oyama-Okubo, N.; Nakayama, M.; Ito, A. Confirmation of structure and synthesis of three new $11 \beta-\mathrm{OH} \mathrm{C} \mathrm{C}_{20}$ gibberellins from loquat fruit. Tetrahedron 2008, 64, 4835-4851. [CrossRef] 
4. Mander, L.N. Twenty years of gibberellin researchelectronic supplementary information (ESI) available: Functionality patterns for naturally occurring gibberellins (gan). See http://www.Rsc.Org/suppdata/np/ b0/b007744p. Nat. Prod. Rep. 2003, 20, 49-69. [CrossRef] [PubMed]

5. Murase, K.; Hirano, Y.; Sun, T.P.; Hakoshima, T. Gibberellin-induced della recognition by the gibberellin receptor gid1. Nature 2008, 456, U459-U463. [CrossRef] [PubMed]

6. Bergner, C.; Lischewski, M.; Adam, G.; Sembdner, G. Biological activity of gibberellin analogues. Planta 1982, 155, 231-237. [CrossRef] [PubMed]

7. Mander, L.N.; Sherburn, M.; Camp, D.; King, R.W.; Evans, L.T.; Pharis, R.P. Effects of D-ring modified gibberellins on flowering and growth in Lolium temulentum. Phytochemistry 1998, 49, 2195-2206. [CrossRef]

8. Chen, J.; Sun, Z.; Zhang, Y.; Zeng, X.; Qing, C.; Liu, J.; Li, L.; Zhang, H. Synthesis of gibberellin derivatives with anti-tumor bioactivities. Bioorg. Med. Chem. Lett. 2009, 19, 5496-5499. [CrossRef] [PubMed]

9. Zhang, Y.; Zhang, H.; Chen, J.; Zhao, H.; Zeng, X.; Zhang, H.; Qing, C. Antitumor and antiangiogenic effects of ga-13315, a gibberellin derivative. Investig. New Drugs 2012, 30, 8-16. [CrossRef] [PubMed]

10. Gao, F.; Hu, T.; Tan, W.; Yu, C.; Li, Z.; Zhang, L.; Duan, L. Photoprotectant improves photostability and bioactivity of abscisic acid under uv radiation. J. Photochem. Photobiol. B-Biol. 2016, 158, 99-104. [CrossRef] [PubMed]

11. Zong, G.; Liang, X.; Zhang, J.; Duan, L.; Tan, W.; Wang, D. Synthesis and plant growth regulation activity of $\alpha$-D-Man $p$ NAc- $(1 \rightarrow 2)-[\alpha$-L-Rhap-( $1 \rightarrow 3)$-] $\alpha$-L-Rha $p-(1 \rightarrow 4)-\beta$-D-GlupNAc- $(1 \rightarrow 3)-\alpha$-L-Rha $p$, the repeating unit of $O$-antigen of Rhizobium trifolii 4s. Carbohydr. Res. 2014, 388, 87-93. [CrossRef] [PubMed]

12. Zhu, X.; Tan, W.; Zhou, F.; Li, Z.; Duan, L. The effect of phosphate buffer solutions on uniconazole complexation with hydroxypropyl- $\beta$-cyclodextrin and methyl- $\beta$-cyclodextrin. J. Incl. Phenom. Macrocycl. Chem. 2012, 73, 193-198. [CrossRef]

13. Zhou, F.; Ran, J.; Tan, W.; Li, Z.; Duan, L. Synthesis and biological activity of aryamido-cyclopropanecarboxylic acid. Chin. J. Pestic. Sci. 2013, 5, 490-495.

14. Meldal, M.; Tornoe, C.W. Cu-catalyzed azide-alkyne cycloaddition. Chem. Rev. 2008, 108, $2952-3015$. [CrossRef] [PubMed]

15. Pedersen, D.S.; Abell, A. 1,2,3-Triazoles in peptidomimetic chemistry. Eur. J. Organ. Chem. 2011, 2011, 2399-2411. [CrossRef]

16. Beck, E.J.; Twitchin, B.; Mander, L.N. Radio labeling of the gibberellin plant growth inhibitor 16,17-dihydro-GA5. Can. J. Chem. 2004, 82, 293-300. [CrossRef]

17. Huigens, R.W., 3rd; Morrison, K.C.; Hicklin, R.W.; Flood, T.A., Jr.; Richter, M.F.; Hergenrother, P.J. A ring-distortion strategy to construct stereochemically complex and structurally diverse compounds from natural products. Nat. Chem. 2013, 5, 195-202. [CrossRef] [PubMed]

18. Ghosh, P.; Aube, J. Resolution of carboxylic acids using copper(I)-promoted removal of propargylic esters under neutral conditions. J. Organ. Chem. 2011, 76, 4168-4172. [CrossRef] [PubMed]

19. Macmillan, J.; Willis, C.L. Partial synthesis of $\left[1 \beta, 2 \beta-{ }^{2} \mathrm{H}_{2}\right]-,\left[2 \beta-{ }^{2} \mathrm{H}\right]-$, and $\left[2 \alpha^{2} \mathrm{H}\right]-$ Gibberellin-A1. J. Chem. Soc.-Perkin Trans. 1 1986, 309-313. [CrossRef]

20. Dolan, S.C.; Macmillan, J. Partial synthesis of the $15 \beta$-hydroxygibberellins $\mathrm{A}_{67}$ and $\mathrm{A}_{68}$ and of 15 $\beta$-hydroxygibberellins $A_{1}$ and $A_{3}$. J. Chem. Soc.-Perkin Trans. 1 1985, 2741-2746. [CrossRef]

21. Chalmers, B.A.; Xing, H.; Houston, S.; Clark, C.; Ghassabian, S.; Kuo, A.; Cao, B.; Reitsma, A.; Murray, C.-E.P.; Stok, J.E.; et al. Validating eaton's hypothesis: Cubane as a benzene bioisostere. Angew. Chem. 2016, 55, 3580-3585. [CrossRef] [PubMed]

22. Brase, S.; Gil, C.; Knepper, K.; Zimmermann, V. Organic azides: An exploding diversity of a unique class of compounds. Angew. Chem. 2005, 44, 5188-5240. [CrossRef] [PubMed]

23. Kim, C.U.; Misco, P.F. New oxidatively removable carboxy protecting groups. Tetrahedron Lett. 1985, 26, 2027-2030. [CrossRef]

24. Yoo, S.E.; Kim, H.R.; Yi, K.Y. Oxidative debenzylation of 4-methoxy- $\alpha$-methylbenzyl esters. Tetrahedron Lett. 1990, 31, 5913-5916. [CrossRef]

25. Kirkwood, P.S.; Macmillan, J.; Sinnott, M.L. Rearrangement of the lactone ring of gibberellin- $\mathrm{A}_{3}$ in aqueous alkali-Participation of the ionized 3-hydroxy-group in an anti $S_{\mathrm{N}} 2^{\prime}$ reaction. J. Chem. Soc.-Perkin Trans. 1 1980, 2117-2121. [CrossRef]

26. Oh, K.; Yamada, K.; Asami, T.; Yoshizawa, Y. Synthesis of novel brassinosteroid biosynthesis inhibitors based on the ketoconazole scaffold. Bioorg. Med. Chem. Lett. 2012, 22, 1625-1628. [CrossRef] [PubMed] 
27. Nishijima, T.; Katsura, N. A modified micro-drop bioassay using dwarf rice for detection of femtomol quantities of gibberellins. Plant Cell Physiol. 1989, 30, 623-627.

28. Serebryakov, E.P.; Agnistikova, V.N.; Suslova, L.M. Structure-activity study of gibberellins. Part 1. Growth-promoting activity of some selectively modified gibberellins. Phytochemistry 1984, 23, 1847-1854. [CrossRef]

Sample Availability: Samples of the compounds 10a-10o are available from the authors.

(C) 2017 by the authors. Licensee MDPI, Basel, Switzerland. This article is an open access article distributed under the terms and conditions of the Creative Commons Attribution (CC BY) license (http:/ / creativecommons.org/licenses/by/4.0/). 